\title{
Effects of Coadministration of Extract of Carica papaya Linn (family Cariaceae) on Activity of Two Oral Hypoglycemic Agents
}

\author{
TO Fakeye*, T Oladipupo, O Showande and Y Ogunremi
}

Department of Clinical Pharmacy \& Pharmacy Administration, University of Ibadan, Ibadan, Nigeria

\begin{abstract}
Purpose: To investigate the interacting effects of co-administration of Carica papaya leaf extract on the hypoglycemic activity of metformin and glimepiride in an animal model.

Method: Experimental factorial design was used to evaluate the individual and interaction influence of three variables ie nature $(N)$, dose administered $(C)$ and duration of administration $(D)$, in a $2^{3}(=8)$ employed at two levels - "high" and "low" - on blood glucose of diabetic rats on administration of ethanolic leaf extract of Carica papaya and two hypoglycemic agents, metformin and glimepiride. Unpaired t-test was used to test for significant difference due to administration of the combination

Results: Extract of Carica papaya at $5.0 \mathrm{mg} / \mathrm{kg}$ produced significant blood glucose reduction with no significant reduction at the higher dose of $10 \mathrm{mg} / \mathrm{kg}(p>0.05)$. Changing nature from "low" (Carica papaya extract) to "high" (glimepiride or metformin) did not significantly change hypoglycemic activity. Generally, the ranking of the interacting effects was ND>CD>>NC for glimepiride/extract, and $C D>N D>N C$ for metformin/extract. Administration of higher dose of the extract led to significant $(p<0.01)$ increase in onset of activity of glimepiride. The onset of activity of metformin was not affected, but a significant lowering $(p<0.05)$ of blood glucose was observed at $24 \mathrm{hr}$ with all combinations of extract and metformin.

Conclusion: Leaf extract of Carica papaya significantly delays the onset of hypoglycaemic activity of glimepiride, and increases the hypoglycaemic effect of metformin with the variables interacting differently for each drug-extract combinations.
\end{abstract}

Keyword: Carica papaya extract, glimepiride, metformin, interaction, blood glucose, mice

*Correspondence E-mail : titifakeye@yahoo.com; to.fakeye@mail.ui.edu.ng 


\section{INTRODUCTION}

Diabetes mellitus is a chronic disease caused by inherited or acquired deficiency of insulin production or resistance to action of the produced insulin ${ }^{1}$. This results in an increased concentration of glucose in the blood usually leading to organ damage ${ }^{2}$. Much of the increase in incidence of diabetes worldwide occurs in developing countries with causes such as aging, unhealthy diets, obesity and sedentary lifestyle, with malnutrition-related causes playing predominant roles ${ }^{2,3}$.

Herbs such as bittermelon, garlic and psyllium seeds have been shown to possess antidiabetic activities and when administered concurrently with allopathic drugs, could lead to interactions with increased likelihood of hypoglycaemia 4. The co administration stems from the fact that it is believed sometimes that use of herbs is harmless, even though some drugs with narrow therapeutic index were developed from plants ${ }^{5}$. In spite of this, it is common to find patients in both industrialised and developing countries using herbs with prescribed drugs ${ }^{6,7}$, without informing their health care practitioners. Investigations in Nigeria ${ }^{7,8}$, have shown that a significant number of patients tend to coadminister herbal medications with allopathic drugs.

Carica papaya Linn (Caricaceae), known as pawpaw and papaya ${ }^{9}$, is common in tropical and sub-tropical countries, and some diabetic patients concurrently take leaf extracts of Carica papaya with oral hypoglycaemic prescription drugs ${ }^{8}$. Its biologically active constituents include chymopapain and papain which are used in the treatment of arthritis and digestive disorders. In folkloric medicine, extracts of the fruits are used for a variety of medicinal purposes ranging from treatment of ringworm, malaria and hypertension ${ }^{10}$, while extracts of unripe fruit have been used in treatment of diabetes ${ }^{11,12}$.

In spite of the concurrent use of the extract of Carica papaya with prescription oral hypoglycemic agents in some patients ${ }^{7,8}$, there is a dearth of literature on the effects of the extract on activity of oral hypoglycaemic agents. Thus, the objective of this study was to investigate the effect of Carica papaya ethanolic leaf extracts on hypoglycemic activity of two oral hypoglycemic agents namely glimepiride and metformin, using a diabetic animal model.

\section{METHODOLOGY Plant Materials}

Carica papaya Linn (Caricaceae) leaves were collected from the Botanical Gardens (University of Ibadan) and authenticated at the Department of Pharmacognosy of the University of Ibadan, Nigeria. Herbarium specimen with voucher no 312 were submitted. Young fresh leaves were dried in an oven at $40{ }^{\circ} \mathrm{C}$ for $48 \mathrm{hr}$, powdered, and $500 \mathrm{~g}$ of the powdered leaves was extracted with $2 \mathrm{~L}$ of $96 \%$ ethanol for $24 \mathrm{hr}$. Repeat extraction was done thrice, and the extract obtained was pooled, filtered and distilled. The residue obtained was dissolved in $20 \mathrm{ml}$ of Tween 80 to obtain appropriate concentrations.

\section{Preparation of oral hypoglycemics}

Stock solutions of glimepiride (Aventis Pharm., Lagos), and metformin (Nigerian German Chemical PLC, Lagos) were prepared by triturating the pure powder of the drugs in $20 \%$ Tween 80. Further dilutions were made with distilled water.

\section{Experimental animals}

Healthy male wistar rats weighing between 140 $220 \mathrm{~g}(180.56 \pm 24.91)$ were obtained from the animal house of the College of Medicine, University of Ibadan, Nigeria. Animals were kept in cages and fed standard commercial diet and water ad libitum. Experiments were performed according to the guide for care and use of laboratory animals. Weights of the rats were monitored throughout the period of the experiment. In the appropriate groups, 180 $\mathrm{mg} / \mathrm{kg}$ alloxan monohydrate (Sigma Chemical Company, USA) administered intraperitoneally was used to induce diabetes in the animals.

\section{Determination of the Blood Glucose}

Glucometer (ACU-Chek ${ }^{\circledR}$, Johnson-Johnson, California, USA) was used for the determination of the blood glucose level of the rats. Blood samples were obtained from the cut tail-tip of 
conscious rat. Basal and $48 \mathrm{hr}$ post-induction blood glucose levels of the animals were recorded. Thereafter, the extract, drug or drugextract combinations were administered daily for periods of "short" and "long" duration of 3 or 7 days, respectively. Blood glucose levels were measured at $2 \mathrm{hr}, 12 \mathrm{hr}, 24 \mathrm{hr}, 72 \mathrm{hr}$ and where appropriate, $168 \mathrm{hr}$.

\section{Experimental Protocols}

Factorial experimental design ${ }^{13,14,15,16}$, which can be used to determine factors influencing the quantifiable outcome or response of a study, and the levels of the factors that will maximise the response obtained, was used in this study to evaluate the effect of three independent variables on the response, i.e., blood glucose levels of diabetic rats treated with combination of drug-extract. The magnitudes of interaction between the factors were also evaluated. The relative significance of the interactions between the variables or the factors influencing the outcome of the experiment, and importance of each variable on the measured response (blood glucose) were evaluated.

The variables investigated in this study are Nature of drug (N), Dose (C) and Duration (D) at "low" level denoted by the subscript $L$ and "high" level denoted by the subscript $\mathrm{H}$ on the blood glucose level of alloxan-induced diabetic rats. The extract was assigned "low" nature $\left(2^{3}=8\right)$ factorial design $\left(N_{L}\right)$ and each drug, "high" nature $\left(\mathrm{N}_{\mathrm{H}}\right)$. These factors were combined in a two by three combinations to study the individual and interaction effects of the factors on the blood glucose level. The resulting combinations were $N_{H} C_{L} D_{H}, \quad N_{H} C_{L} D_{L}, \quad N_{H} C_{H} D_{H}, \quad N_{H} C_{H} D_{L}, \quad N_{L} C_{L} D_{H}$, $\mathrm{N}_{\mathrm{L}} \mathrm{C}_{\mathrm{L}} \mathrm{D}_{\mathrm{L}}, \mathrm{N}_{\mathrm{L}} \mathrm{C}_{\mathrm{H}} \mathrm{D}_{\mathrm{H}}$, and $\mathrm{N}_{\mathrm{L}} \mathrm{C}_{\mathrm{H}} \mathrm{D}_{\mathrm{L}}$.

The animals were divided into several groups. All the animals except those administered 20\% Tween 80 only were fasted for $20 \mathrm{hr}$ before administering $180 \mathrm{mg} / \mathrm{kg}$ intraperitoneal alloxan monohydrate. The diabetic state of each rat was assessed by blood glucose level which was measured $48 \mathrm{hr}$ post-alloxan administration. Four animals per group, which presented with significant increase up to $10 \mathrm{mmol} / \mathrm{L}$ blood glucose levels, were used for the experiment.
Each animal in each group was administered 5 $\mathrm{mg} / \mathrm{kg}$ ("low" dose, $\mathrm{C}_{\mathrm{L}}$ ) or $10 \mathrm{mg} / \mathrm{kg}$ ("high" dose, $\mathrm{C}_{\mathrm{H}}$ ) of the extract $\left(\mathrm{N}_{\mathrm{L}}\right)$; glimepiride, "low" - 0.2 $\mathrm{mg} / \mathrm{kg}$, "high" - $0.4 \mathrm{mg} / \mathrm{kg}$; metformin, "low"- 50 $\mathrm{mg} / \mathrm{kg}$, "high"- $100 \mathrm{mg} / \mathrm{kg}$ for either 3 days ("low" duration, $\mathrm{D}_{\mathrm{L}}$ ) or 7 days ("high" duration, $\mathrm{D}_{\mathrm{H}}$ ). The "low" and "high" doses of the drugs were chosen based on prior studies done on animal models $17,18,19$. Another set of four groups of animals were administered glimepiride-extract combinations of "high"-"high", "high"-"low", "low""high", and "low"-"low" doses for 3 days ("low") and 7 days "(high") duration. This was repeated for metformin. Control animals were administered $0.1 \mathrm{ml} 20 \%$ Tween 80 , extract (5 or $10 \mathrm{mg} / \mathrm{kg}$ ), glimepiride (0.2 or $0.4 \mathrm{mg} / \mathrm{kg}$ ), or metformin (50 or $100 \mathrm{mg} / \mathrm{kg}$ ) for the duration of the experiments. Blood glucose levels of diabetic rats were used to calculate the independent and interaction coefficients of the variables.

\section{Determining the Individual Effect}

The individual effect of increasing any of the variables from its "low" to "high" level was determined by summing all the variable results containing "high" level of the variable and subtracting the sum of variables containing "low" level of the variable from it. For example, the effect of increasing nature from "low" to "high" was determined by summing all the variable results of sample containing "high" level of the nature and subtracting the sum of sample containing "low" level of nature using the following equation for nature:

$1 / 4\left[\left(N_{H} C_{L} D_{H}+N_{H} C_{H} D_{L}+N_{H} C_{H} D_{H}+N_{H} C_{L} D_{L}\right)-\right.$

$\left.\left(N_{L} C_{L} D_{L}+N_{L} C_{H} D_{L}+N_{L} C_{H} D_{H}+N_{L} C_{L} D_{H}\right)\right] \ldots$

The amount by which the result of this treatment departed from zero irrespective of whether positive or negative is the quantitative measure of the individual effect of the variable on the diabetic control of the rats obtained from changing the nature.

Similar expressions were applied to determine the individual effect of dose (C) and duration (D) on the glycemic control of the animals. 


\section{Determination of Interaction Effect}

This was used to determine whether there existed any interaction between the variables, and if there was, the trend for each drug-extract combination. To determine whether there exist any interaction between two variables, the results of the combination in which they appeared together at either "high" $(\mathrm{H})$ or "low" (L) levels were summed, and the sum of the other combination subtracted from this to obtain the interaction coefficient. For example, to determine the interaction coefficient for nature $(\mathrm{N})$ and dose (C), the factorial equation below was used:

$1 / 4\left[\left(N_{L} C_{L} D_{H}+N_{L} C_{L} D_{L}+N_{H} C_{H} D_{H}+N_{H} C_{H} D_{L}\right)-\right.$ $\left(N_{L} C_{H} D_{H}+N_{L} C_{H} D_{L}+N_{H} C_{L} D_{H}+N_{H} C_{L} D_{L}\right)$.

A result of zero indicated no interaction, but if the interaction coefficient is significantly removed from zero, it is concluded that the two variables concerned were interacting with each other. The extent of removal from zero is a measure of the interaction. A positive value indicates an additive interaction, while a negative value indicates an opposing interaction.

\section{Statistical Analysis}

Woolfall analysis was used to analyze the individual and interaction effects of the variables used in the study. Unpaired t-test was also used to determine level of significance of difference in blood glucose levels obtained with coadministration of Carica papaya leaf extract, and to evaluate effects of the extract on the activity of each oral hypoglycemic agent. At 95\% confidence interval, significant level was set at $\mathrm{p}<0.05$.

\section{RESULTS}

The combinations obtained were grouped into appropriate sets which made it possible to assess the influence of each variable separately on the hypoglycemic activities of the drug-extract combinations, and to determine whether the variables were interacting or acting independently of one another, and also the combinations of variables that had the greatest influence on the interaction between the drug(s) and extract.
Evaluating the effect of the individual variables, changing nature from "low" (Carica papaya extract) to "high" (drug) ranked lowest (Table 1) except at $12^{\text {th }}$ and $72^{\text {nd }} \mathrm{hr}$ for glimepiride, and $24^{\text {th }}$ to $72^{\text {nd }}$ hr for metformin. For both drugs, the dose $\mathrm{C}$ at which the extract/drug was administered was found to rank highest for the first $12 \mathrm{hr}$ indicating that the dose at which the extract or drug was administered affected the activity more for the first $12 \mathrm{hr}$ for glimepiride, and up to $24 \mathrm{hr}$ for metformin (Table 1). The duration of administration had a significant effect on the activity of Glimepiride-extract and metformin-extract with a ranking of $\mathrm{ND}>\mathrm{CD}>>\mathrm{NC}$ (for the $2^{\text {nd }}, 24^{\text {th }}$ and $72^{\text {nd }} \mathrm{hr}$ ), and $\mathrm{CD}>\mathrm{ND}>\mathrm{NC}\left(12^{\text {th }}\right.$ to the $\left.72^{\text {nd }} \mathrm{hr}\right)$ respectively. The values for the various interactions were generally negative. The onset of hypoglycemic activity of leaf extract of Carica papaya was found to be around $24 \mathrm{hr}$ irregardless of the dose. The activity was found to be significant at the $5 \mathrm{mg} / \mathrm{kg}$ and comparable to glimepiride $(0.2 \mathrm{mg} / \mathrm{kg})$ and metformin $(50 \mathrm{mg} / \mathrm{kg}$ ) (Table 2) though with a longer onset of action than the drugs. The administration of the extract at 10 $\mathrm{mg} / \mathrm{kg}$ increased the onset of activity of glimepiride to $24 \mathrm{hr}$ (Table 3). Generally, administration of "high" dose of the extract in combination with glimepiride increased the onset of activity compared with glimepiride monotherapy $(p<0.01)$ after which there was a transient increase in blood glucose observed at $72 \mathrm{hr}$ followed by decrease in glucose levels (Table 4).

The addition of the extract did not significantly affect the hypoglycemic effect of metformin except with high doses of both $(p<0.05)$ at $2 \mathrm{hr}$ and "high"-"low" metformin-extract at $12 \mathrm{hr}$ $(p<0.05)$. There was a highly significant reduction of blood glucose at $24 \mathrm{hr}$ with all combinations thereafter $(p<0.01)$ which extended to $72 \mathrm{hr}$ except for the "low"-"low" combination. This effect on metformin activity was similar to what was observed with glimepiride except that the intensity of the effect was more obvious with metformin than with glimepiride. 
Fakeye et al

Table 1: Effect of variables on blood glucose levels of animals $(n=4)$

\begin{tabular}{|c|c|c|c|c|}
\hline \multirow{2}{*}{ Individual Variables } & \multicolumn{4}{|c|}{ Time (hr Post Administration) } \\
\hline \multirow{2}{*}{\multicolumn{5}{|c|}{ Glimepiride/Extract }} \\
\hline & & & & \\
\hline Nature & -1.82 & -6.74 & 0.54 & -0.51 \\
\hline Concentration & -4.55 & -2.95 & -0.39 & -0.37 \\
\hline Duration & 1.90 & 3.09 & -0.55 & -0.25 \\
\hline Ranking & $C>D=N$ & $N>D>C$ & $D=N>C$ & $N>C>D$ \\
\hline \multicolumn{5}{|l|}{ Metformin/Extract } \\
\hline Nature & 0.23 & -1.57 & 3.42 & 2.03 \\
\hline Concentration & -2.24 & -3.28 & -0.17 & -0.09 \\
\hline Duration & 1.11 & 3.18 & -1.23 & -1.32 \\
\hline Ranking & $C>D>N$ & $C>D \gg P N$ & $N>D \gg C$ & $N>D \gg C$ \\
\hline Interacting Variables & \multicolumn{4}{|c|}{ Time (hr Post Administration) } \\
\hline \multicolumn{5}{|l|}{ Glimepiride/Extract } \\
\hline $\mathrm{N}-\mathrm{C}$ & -0.28 & 3.24 & -0.05 & -0.04 \\
\hline$N-D$ & -1.48 & -3.05 & 0.51 & 0.21 \\
\hline & 1.04 & -2.61 & -0.49 & -0.15 \\
\hline \multicolumn{5}{|l|}{$C-D$} \\
\hline Ranking & $\begin{array}{l}\mathrm{ND}>\mathrm{CD} \\
>>\mathrm{NC}\end{array}$ & $N C>N D>C D$ & $N D=C D>>N C$ & $N D>C D>>N C$ \\
\hline \multicolumn{5}{|l|}{ Metformin/Extract } \\
\hline $\mathrm{N}-\mathrm{C}$ & 1.82 & 2.72 & 0.17 & 0.17 \\
\hline$N-D$ & -2.11 & -2.85 & 0.76 & 0.21 \\
\hline$C-D$ & 0.12 & -3.33 & -1.11 & -0.87 \\
\hline Ranking & $\begin{array}{l}\mathrm{ND}>\mathrm{NC} \\
>\mathrm{CD}\end{array}$ & $C D>N D>N C$ & $\mathrm{CD}>\mathrm{ND} \gg \mathrm{NC}$ & $\mathrm{CD}>\mathrm{ND}>\mathrm{NC}$ \\
\hline
\end{tabular}

Key: $N=$ Nature; $\quad C=$ Concentration; $\quad D=$ Duration

Table 2: Hypoglycemic effect of Carica papaya ethanolic leaf extract in diabetic rats $(n=4)$

\begin{tabular}{|c|c|c|c|c|c|c|c|}
\hline \multirow{2}{*}{$\begin{array}{l}\text { Group/Treatmen } \\
\mathrm{t}\end{array}$} & \multirow{2}{*}{$\begin{array}{c}\text { Duration } \\
\text { (days) }\end{array}$} & \multicolumn{6}{|c|}{ Blood glucose level (mmol/L) $\mathrm{hr}$ post administration (mean \pm standard deviation) } \\
\hline & & $0 \mathrm{hr}$ & $2 \mathrm{hr}$ & $12 \mathrm{hr}$ & $24 \mathrm{hr}$ & $72 \mathrm{hr}$ & $168 \mathrm{hr}$ \\
\hline Low (5mg/kg) & $\begin{array}{l}7 \text { (High) } \\
3 \text { (Low) }\end{array}$ & $\begin{array}{l}13.85 \pm 9.68 \\
10.05 \pm 6.80\end{array}$ & $\begin{array}{l}12.95 \pm 5.74 \\
11.13 \pm 7.46\end{array}$ & $\begin{array}{l}17.9 \pm 10.75 \\
6.53 \pm 4.53\end{array}$ & $\begin{array}{l}2.65 \pm 1.46 \\
2.63 \pm 0.75\end{array}$ & $\begin{array}{l}2.55 \pm 1.64 \\
2.63 \pm 0.74\end{array}$ & $\begin{array}{l}3.65 \pm 0.58 \\
\text { ND }\end{array}$ \\
\hline High $(10 \mathrm{mg} / \mathrm{kg})$ & $\begin{array}{l}7 \text { (High) } \\
3 \text { (Low) }\end{array}$ & $\begin{array}{l}12.75 \pm 13.70 \\
11.48 \pm 2.03\end{array}$ & $\begin{array}{l}10.23 \pm 9.00 \\
10.3 \pm 2.10\end{array}$ & $\begin{array}{l}6.47 \pm 5.03 \\
5.58 \pm 2.47\end{array}$ & $\begin{array}{l}1.23 \pm 0.23 \\
3.38 \pm 0.33\end{array}$ & $\begin{array}{l}1.83 \pm 1.23 \\
2.68 \pm 0.35\end{array}$ & $\begin{array}{l}3.6 \pm 1.77 \\
\text { ND }\end{array}$ \\
\hline $\begin{array}{l}\text { Negative control } \\
\text { (Alloxan } \\
\text { monohydrate } \\
180 \mathrm{mg} / \mathrm{kg} \text { ) }\end{array}$ & & $15.9 \pm 5.10$ & ND & ND & ND & $14.68 \pm 4.27$ & $16.45 \pm 2.57$ \\
\hline $\begin{array}{l}\text { Positive } \begin{array}{r}\text { control } \\
\text { (non diabetic } \\
\text { rats) }\end{array} \\
\end{array}$ & & $3.35 \pm 0.19$ & ND & ND & ND & $3.38 \pm 0.29$ & $3.3 \pm 0.16$ \\
\hline
\end{tabular}

Key: Low=3 days $\quad$ High $=7$ days $\quad N D=$ Not determined 
Fakeye et al

Table 3: Hypoglycemic effect of the oral hypoglycemic agents in diabetic rats $(n=4)$

\begin{tabular}{|c|c|c|c|c|c|c|c|}
\hline \multirow[t]{2}{*}{ Group/Treatment } & \multirow{2}{*}{$\begin{array}{l}\text { Duration } \\
\text { (days) }\end{array}$} & \multicolumn{6}{|c|}{ Blood glucose level $x$ hr post treatments (mean \pm standard deviation) } \\
\hline & & $0 \mathrm{hr}$ & $2 \mathrm{hr}$ & $12 \mathrm{hr}$ & $24 \mathrm{hr}$ & $72 \mathrm{hr}$ & $168 \mathrm{hr}$ \\
\hline \multicolumn{8}{|l|}{ Glimepiride } \\
\hline $0.2 \mathrm{mg} / \mathrm{kg}$, low & 7 (High) & $11.98 \pm 4.72$ & $10.45 \pm 3.75$ & $2.25 \pm 0.8$ & $2.08 \pm 0.81$ & $2.05 \pm 0.77$ & $2.06 \pm 0.78$ \\
\hline $0.4 \mathrm{mg} / \mathrm{kg}$, high & $\begin{array}{l}3 \text { (Low) } \\
7 \text { (High) }\end{array}$ & $\begin{array}{l}11.4 \pm 4.65 \\
8.9 \pm 2.22\end{array}$ & $\begin{array}{l}10.55 \pm 3.96 \\
6.15 \pm 1.12\end{array}$ & $\begin{array}{l}2.23 \pm 0.54 \\
2.56 \pm 1.32\end{array}$ & $\begin{array}{l}2.23 \pm 0.79 \\
1.75 \pm 0.70\end{array}$ & $\begin{array}{l}2.18 \pm 0.78 \\
1.73 \pm 0.56\end{array}$ & $\begin{array}{l}\text { ND } \\
1.83 \pm 0.66\end{array}$ \\
\hline \multicolumn{8}{|l|}{ Metformin } \\
\hline $50 \mathrm{mg} / \mathrm{kg}$ & 7 & $14.20 \pm 2.29$ & $10.43 \pm 0.53$ & $8.53 \pm 0.58$ & $6.68 \pm 0.28$ & $5.03 \pm 0.37$ & $3.15 \pm 0.37$ \\
\hline $100 \mathrm{mg} / \mathrm{kg}$ & $\begin{array}{l}3 \\
7\end{array}$ & $\begin{array}{l}13.95 \pm 1.63 \\
10.15 \pm 0.96\end{array}$ & $\begin{array}{l}9.98 \pm 1.76 \\
8.83 \pm 0.84\end{array}$ & $\begin{array}{l}6.78 \pm 1.09 \\
6.75 \pm 0.50\end{array}$ & $\begin{array}{l}5.10 \pm 0.81 \\
5.55 \pm 0.65\end{array}$ & $\begin{array}{l}3.85 \pm 0.43 \\
3.80 \pm 0.18\end{array}$ & $\begin{array}{l}\text { ND } \\
3.00 \pm 0.35\end{array}$ \\
\hline & 3 & $12.55 \pm 1.58$ & $10.98 \pm 1.34$ & $7.83 \pm 1.21$ & $6.23 \pm 0.91$ & $5.23 \pm 0.66$ & ND \\
\hline
\end{tabular}

Table 4: Effect of coadministration of extract of Carica papaya extract on hypoglycemic effect of glimepiride $(n=4)$ for 7 days duration.

\begin{tabular}{|c|c|c|c|c|c|c|}
\hline \multirow[t]{2}{*}{ Group } & \multirow{2}{*}{$\begin{array}{l}\text { Treatment/ } \\
\text { Doses }\end{array}$} & \multicolumn{5}{|c|}{ Blood glucose levels (mmol/L) hr post treatment (mean \pm std deviation) } \\
\hline & & $2 \mathrm{hr}$ & $12 \mathrm{hr}$ & $24 \mathrm{hr}$ & $72 \mathrm{hr}$ & $168 \mathrm{hr}$ \\
\hline \multirow[t]{2}{*}{ Glimepiride } & $0.2 \mathrm{mg} / \mathrm{kg}$ (low) & $10.50 \pm 1.26$ & $2.24 \pm 0.24$ & $2.13 \pm 0.26$ & $2.11 \pm 0.26$ & $2.08 \pm 0.39$ \\
\hline & $0.4 \mathrm{mg} / \mathrm{kg}$ (high) & $5.68 \pm 0.37$ & $2.54 \pm 0.34$ & $1.69 \pm 0.19$ & $1.70 \pm 0.15$ & $1.83 \pm 0.33$ \\
\hline \multirow[t]{4}{*}{$\begin{array}{l}\text { Glimepiride } \\
\text { + Extract }\end{array}$} & $\begin{array}{l}\text { Glimepiride } \\
\text { low/Carica } \\
\text { papaya low }\end{array}$ & $8.08 \pm 1.95$ & $2.48 \pm 0.26$ & $1.25 \pm 0.15^{\star *}$ & $6.03 \pm 0.51^{* *}$ & $3.43 \pm 0.6^{\star *}$ \\
\hline & $\begin{array}{l}\text { Glimepiride } \\
\text { low/Carica } \\
\text { papaya high }\end{array}$ & $12.05 \pm 4.65$ & $10.68 \pm 4.81^{\star *}$ & $1.40 \pm 0.29 * *$ & $2.35 \pm 0.73$ & $1.85 \pm 0.27$ \\
\hline & $\begin{array}{l}\text { Glimepiride } \\
\text { high/Carica } \\
\text { papaya low }\end{array}$ & $6.00 \pm 0.51$ & $6.00 \pm 0.51$ & $1.25 \pm 0.20^{*}$ & $4.50 \pm 0.47$ & $2.73 \pm 0.41$ \\
\hline & $\begin{array}{l}\text { Glimepiride } \\
\text { high/Carica } \\
\text { papaya high }\end{array}$ & $9.42 \pm 3.12^{*}$ & $9.28 \pm 3.28 * \star$ & $1.40 \pm 0.29$ & $9.15 \pm 3.18^{\star \star}$ & $4.35 \pm 2.56$ \\
\hline \multirow[t]{2}{*}{ Metformin } & $50 \mathrm{mg} / \mathrm{kg}$ (low) & $10.43 \pm 0.53$ & $8.53 \pm 0.58$ & $6.68 \pm 0.28$ & $5.03 \pm 0.37$ & $3.15 \pm 0.37$ \\
\hline & 100mg/kg (high) & $8.83 \pm 0.84$ & $6.75 \pm 0.50$ & $5.55 \pm 0.65$ & $3.80 \pm 0.18$ & $3.00 \pm 0.35$ \\
\hline \multirow[t]{4}{*}{$\begin{array}{l}\text { Metformin } \\
\text { Extract }\end{array}$} & $\begin{array}{l}\text { Metformin low/ } \\
\text { Carica papaya } \\
\text { low }\end{array}$ & $16.60 \pm 5.17^{\star}$ & $6.48 \pm 1.55$ & $1.53 \pm 0.44^{\star \star}$ & $6.90 \pm 3.91$ & $3.83 \pm 0.59$ \\
\hline & $\begin{array}{l}\text { Metformin low/ } \\
\text { Carica papaya } \\
\text { high }\end{array}$ & $10.90 \pm 4.18$ & $6.23 \pm 3.24$ & $2.20 \pm 0.43^{\star \star}$ & $1.53 \pm 0.53^{*}$ & $2.43 \pm 0.50$ \\
\hline & $\begin{array}{l}\text { Metformin high/ } \\
\text { Carica papaya } \\
\text { low }\end{array}$ & $8.18 \pm 1.83$ & $3.23 \pm 0.40^{*}$ & $1.78 \pm 0.26^{\star \star}$ & $1.45 \pm 0.69$ & $3.50 \pm 0.91$ \\
\hline & $\begin{array}{l}\text { Metformin high/ } \\
\text { Carica papaya } \\
\text { high }\end{array}$ & $18.33 \pm 6.00 *$ & $5.45 \pm 2.02$ & $1.83 \pm 0.45^{\star \star}$ & $1.55 \pm 0.24$ & $3.73 \pm 0.61$ \\
\hline \multicolumn{7}{|c|}{$\begin{array}{l}\text { Key: } \\
\text { * }_{-} p<0.05 \\
\star \star-p<0.01\end{array}$} \\
\hline
\end{tabular}




\section{DISCUSSION}

The onset of hypoglycaemic activity of leaf extract of Carica papaya was as confirmed by a previous study ${ }^{11}$. Generally, the extract of Carica papaya was as effective as glimepiride and metformin as hypoglycemic agent though the drugs had a faster onset of action.

The ranking of the interacting variables showed that the interactions between the drugs and the extract were influenced by various interactions between the factors which may not be unconnected with the different mechanisms of action of the two drugs. Nature and concentration of drug administered interacted greatly with duration of administration, and the effect of ND and CD was much greater than NC to give a ranking of $\mathrm{ND}>\mathrm{CD}>>\mathrm{NC}$ for glimepiride-extract combination with nature and concentration having relatively negligible interaction. However, the effect of the duration of administration depended greatly on the nature and dose of the material being administered. This is to be expected since the duration would normally depend on some known properties of the active materials such as its strength of activity (nature) and on the concentration (dose) of the material in the dosage form or extract. Nature, and concentration, to a large extent functioned independently of each other showing that the dose of the drug/extract to be co administered will not be dependent on the nature. Metformin-extract, on the other hand, gave a more consistent ranking of $C D>N D>N C$ showing that duration of administration also depended on the dose administered and nature as it did for the glimepiride-extract though in a reverse order. NC was also shown to be independent of each other. The negative values suggest the complexity of interactions in the administered combinations.

The tendency to increase the onset of action of glimepiride by the extract at a "high" dose of the extract for the first $24 \mathrm{hr}$ might be due to delay in the absorption of the drug (since they were both administered orally) by initially binding up part of the drug and preventing it from getting into the systemic circulation from the gastrointestinal tract, or by stimulating the production and activity of enzymes that degrade some of the drug especially in the gut. Generally, administration of the metformin-extract combination caused a more significant lowering of blood glucose when compared with metformin monotherapy at different periods of sampling exhibiting an additive effect as a result of interaction between the dose and duration of administration.

The interaction between the drug-extract combinations was different for each drug. This could be due to the difference in mechanisms of action of metformin and glimepiride. Oke ${ }^{11}$ has proposed that the extract of Carica papaya lowers blood glucose in a similar manner to chlorpropamide. Glimepiride is known to lower glucose concentration in the blood, primarily by stimulating a first-phase release of insulin from functioning pancreatic beta-cells in response to food and causes an increased sensitivity of body cell to endogenous insulin, hence decreasing insulin resistance. Metformin on the other hand stimulates tissue uptake of glucose and increases insulin receptor binding.

The observed interaction between the extracts of Carica papaya and glimepiride in diabetic rats could be said to lead to a delay in onset of action followed by a synergistic effect. A synergistic effect was observed with metformin.

\section{CONCLUSION}

The administration of Carica papaya leaf extract with glimepiride or metformin led to significant interactions which affected the oral hypoglycaemic activities of the drugs. There may be a need for more studies to evaluate the long term effect of the co administration of the extract and drug(s) so as to evaluate the problems involved in the practise, a need for public enlightenment on the dangers of co administration of extracts of Carica papaya with oral hypoglycemic or any other herbal product since this may lead to very low blood glucose as observed in this study. Future studies may be directed towards elucidation of the pathway of mechanism of the interaction observed between each drug and the extract of Carica papaya.

\section{REFERENCES}

1. Setter S.M; White J.R and Campbell R.K. Diabetes: Textbook of therapeutics, drugs and diseases management, Ed Herfindal E.T and Crowley D.R; Lippincott; Williams and 
Wilkins Publishing Company, United States of America. 2000, pp 45-50

2. World Health Organisation. Definition, diagnosis and classification of Diabetes Mellitus and its complications. Reports of a WHO Consultation. Geneva: World Health Organisation 1999 pp1-33.

3. Fioretto P, Steffes MW, Sutherland DER. Reversal of lesions of diabetes nephropathy after the pancreas transplantation. New England Journal of Medicine 1998, 330: 69-75.

4. DeSmet PAGM \& D'Arcy PF. Drug interactions with herbal and non-orthodox remedies. In: D'Arcy PF, McElnay JC, Welling PG, eds. Mechanisms of Drug Interactions. New York, NY: Springer-Verlag: 1996. pp 327-352

5. Kuhn M. Herbal remedies: Drug-herb interactions. Critical Care Nurse, 2002. 22(2): 22-32.

6. Eisenberg DM, Davis RB, Ettner SL, Appel S, Wilkey S, Van Rompay $M$ \& Kessler RC.: Trends in alternative medicine use in the United States, 1990-1997: results of a follow-up national survey. Journal of American Medical Association 1998. 280: 1569-1575

7. Fakeye TO, Abu T \& Adebisi O. A survey of the use of herbs among patients attending secondary health care facilities in Southwestern Nigeria. Journal of Herbal Pharmacotherapy 2007 (In press)

8. Oyelola O. Evaluation of the hypoglycemic activity of Treculia Africana Decne (root) in normal and diabetic rats. M. Pharm (Clinical Pharmacy) Dissertation University of Ibadan Nigeria, 2005.

9. NAPRALERT $T^{\text {Sm }}$ University of Illinois At Chicago Programme for Collaborative Research in the Pharmaceutical Sciences. www.napralert.org/search/verify/default.aspx .15/08/2006

10. Sofowa A. Research on medicinal plants and traditional medicine in Africa. Journal of Alternative and Complementary Medicine 1996, 2(3), 365-372.
11. Oke J.M. Antidiabetic potency of pawpaw. African Journal of Biomedical Research 1998, 1: 3134.

12. Cheryl A Lans. Ethnomedicines used in Trinidad and Tobago for urinary problems and diabetes mellitus. Journal of Ethnobiology \& Ethnobiomedicine 2006, 2: 45 www.ethnobiomed.com/content/2/1/45

13. Woolfal R.C. An approach to product formulation. Soap Perfume Cosmetics. 1964, 37: 965970.

14. Itiola O.A and Pilpel N. Effects of interacting variables on the disintegration and dissolution of metronidazole tablets. Pharmazie, 1996, 51, 987-989.

15. Fakeye TO, Itiola OA, George AO \& Odelola HA. Antimicrobial property of Picralima nitida stem bark extract in cream formulations. Pharmaceutical Biology 2004. Vol 42 (4-5), 274-279.

16. Shaw R, Festing MFW, Peers I \& Furlong L Use of factorial designs to optimize animal experiments and reduce animal use. Institute for Laboratory Animal Research Journal. 2002. 43(4): 223-232

17. Yasuda $N$, Inuoe $T$, Nagakura $T$, Yamazaki K, Kira $K$, Saeki $T$ \& Tanaka I. Enhanced secretion of glucagon-like peptide 1 by biguanide compounds. Biochemical and Biophysical Research Communications. 2002. 298(5): 779-784

18. Tanaka Y, Uchiro H, Shimizu T, Yoshil H, Niwa $M$, Ohmura $C$, Mitsuhashi $N$ Onuma $T \&$ Kawamori R. Effect of metformin on advanced glycation endpoint formation and peripheral nerve function in streptozotocininduced diabetic rats. European Journal Pharmacology. 1999. 376(1-2): 17-22

19. Mark $M \&$ Grell W. Hypoglycemic effects of the novel antidiabetic agent repaglinide in rats and dogs. Britain Journal Pharmacology 1997. 121(8): 1597-1604 